\title{
Demasiado Benjamin*
}

\section{Too much Benjamin}

\author{
Hans UlRICH GumbreCht \\ Stanford University \\ Estados Unidos \\ Correo: sepp@stanford.edu
}

DOI 10.48102/hyg.vi54.3I5

Artículo recibido: 5/09/2019

Artículo aceptado: 25/10/2019

Lo que cautiva a tantos de los lectores de Walter Benjamin -y que ya desde décadas los hace admiradores adictos de sus palabras- es una confluencia de imágenes sugestivas y tesis fuertes -atípica para la tradición, por lo demás bastante espesa, de las humanidades-, que suele escenificarse como inversión de puntos de vista convencionales. Eso se evidencia de manera particular en los textos últimos -y probablemente más populares- de Benjamin. El ensayo largo La obra de arte en la época de su reproductibilidad técnica comprime, en la metáfora del estatus de la cámara de cine como implemento quirúrgico, la esperanza (una vez desvanecida el aura) de una nueva función del arte, tanto crítica como apta para las masas -la cual pretende establecerse como "politización" del mismo arte (y como polo opuesto a la "estetización" en apariencia fascista de la política)-. Las tesis Sobre el concepto de historia van desde la imagen del enano jorobado manejando el autómata de ajedrez que es el "materialismo histórico",

* La versión original de este artículo fue publicada en la revista Cicero Magazin für politische Kultur con el título "Der falsche Seher", el 17 de junio de 2009 (Hans Ulrich Gumbrecht). Agradecemos las facilidades otorgadas para la traducción y reproducción del texto con algunas modificaciones. 
pasan por el montaje que Benjamin hace en torno al Angelus Novus de Paul Klee y por su recuerdo de los relojes detenidos por balas revolucionarias, hasta la crítica de un tiempo teleológicamente vacío (supuestamente "socialdemócrata") -y a favor de un "tiempo de ahora’ en el que están incrustadas astillas del tiempo mesiánico”-.

Tal como pasa con los anuncios publicitarios o con las pancartas electorales más eficientes, para el lector siempre es indudable qué debe considerar como bueno y qué como malo, sin que sea entendible con facilidad por qué los valores se distribuyen de esta y no de otra manera. Combinar intuiciones tan fugaces como excéntricas con conceptos o imágenes literariamente fuertes es el talento particular de Benjamin.

Este efecto es tanto más notable (aunque desde hace tiempo se acepta como natural) cuanto que casi ninguno de los pronósticos historico-filosóficos por él disparados en tan gran cantidad, ha sido confirmado en su futuro y en nuestro pasado más reciente. En lugar de romper un aura, la reproductibilidad técnica del arte ha llevado en realidad a que hoy día aun enmarquemos pancartas-de-exhibición y las tratemos como objetos de culto. Gracias al concepto optimista-teleológico de historia (denunciado por Benjamin como "vacío") de la socialdemocracia y a la paciencia que lo caracteriza y que con dificultad se puede calificar de "revolucionario", la Unión Europea se ha convertido en la zona de la clase media más amplia y opulenta que jamás el mundo ha visto, mientras que los "tiempos de ahora" cargados de importancia mesiánica, a menudo resultaron ser el origen de represión y empobrecimiento común (como la Revolución soviética de Octubre y la Revolución comunista en Cuba) o -en el caso más moderado- son recordados hoy como meras anécdotas carnavalescas (como, por ejemplo, el mayo francés de 1968).

No obstante, los pronósticos y las tesis de Walter Benjamin se han mantenido de manera peculiar frente a un demérito de lo intelectual. Sus seguidores no sólo reclaman con razón -apologeticamente- que el cumplimiento o no cumplimiento de los componentes de un juicio dirigidos al futuro no pueden, en última instancia, ser criterio de su calidad. Quienquiera que exprese escepticismo hacia Benjamin se 
hace sospechoso además de no tener empatía por él -víctima del nazismo-y, por lo tanto, de tomar el partido moralmente turbio de los "vencedores". Esta defensa moralizante de Benjamin queda sobrepasada por la versión histérica que en especial en el caso de Giorgio Agamben parece haberse convertido en una segunda naturaleza argumentativa: según ella, sólo aquellos contemporáneos que desconocen la medida en la que -así lo formula Benjamin- "el 'estado de excepción’ en que ahora vivimos es en verdad la regla”, consideran nuestro presente vivible (o incluso lo ven como la realización de una utopía socialdemócrata); es decir: caen en descrédito moral aquellos que no consideran situaciones de excepción como prueba de que el campo de concentración se haya convertido en la condición general de la vida humana. Igual que en el cuento de Hans Christian Andersen "El traje nuevo del emperador", parece que uno debe haber preservado la libertad de ser ingenuo para no contagiarse por tan desenfrenada ofuscación.

Ciertamente y de nuevo, el hecho de permanecer incumplidos los pronósticos y los juicios en los cuales se basan, no por fuerza perjudica su calidad intelectual. Lo sorprendente entonces es, antes que nada, lo fuerte y hasta amenazante que se ha establecido entretanto el tabú que blinda la obra completa de Benjamin no sólo contra cualquier crítica sino incluso contra valoraciones reservadas. Falta de entusiasmo o falta de aprobación por los escritos de Benjamin hacen del lector una figura deficiente, en vez de poner en tela de juicio al autor. En el fondo, entonces, si el entusiasmo personal por Benjamin está ausente o si se perdió a lo largo del tiempo, no se puede caer más bajo -y por lo tanto uno se puede aventurar sin poder perder más el prestigio a la pregunta de cómo debe evaluarse la calidad de los argumentos de Benjamin que están detrás de las profecías fallidas-. Luego se vuelve incontenible la convicción de que dicha calidad argumentativa no corresponde en absoluto con la brillantez retórica con la que Benjamin presentó sus tesis. En el ensayo sobre la "obra de arte" subestima la fuerza de la autonomía estética junto con sus funciones, originadas en el siglo de la Ilustración y las confunde con residuos de rituales religiosos de la Edad Media. Siguiendo aparen- 
temente el eslogan, carente de la complejidad adecuada, de que "las opiniones dominantes siempre son las opiniones de los dominadores", en las tesis "Sobre el concepto de historia" asume que el esfuerzo historicista por la objetividad siempre sirve a los "vencedores", mientras que en apariencia supone que la carga del presente prescrita por él -programáticamente ligado a cuestiones de clase-con "astillas" del futuro mesiánico, sacadas del pasado, está dotada de una "objetividad" superior, moralmente fundada.

Es muy probable que, desde nuestro punto de vista de lo que todavía son los principios del siglo xxI, la propuesta de Walter Benjamin -quizá insuperable en su excentricidad en el ámbito de la izquierda de alrededor de 1940- de encomendar las jugadas de ajedrez del materialismo histórico al enano jorobado de la teología, parezca muy simpática. Pero es un acto de autoabandono intelectual permitir que tales sentimientos de simpatía tomen el lugar de una comprensión escudrińadora con meticulosidad. Esto se aplica tanto más a una generación cuyo valor de pensar por sí misma se ve cada vez más atrofiado frente al reflejo alejandrino de no aceptar pensamientos "nuevos" - hasta que uno no haya convenido de que se encuentran preformulados en algún clásico-. Es hora de empezar en serio y con la paciencia necesaria un trabajo de distinguir entre aquellas partes de la obra de Benjamin que se han vuelto irrelevantes, aquellas que han permanecido históricamente interesantes y, por último, aquellas que han conservado o desarrollado un interés sistemático para nosotros. Un poco menos de Benjamin seguramente sería un más. Más sobre todo porque volvería a conquistar el espacio para nuestro pensamiento propio y contemporáneo. 圈

Traducción de Dominik Hofmann 